\title{
Correction to: Twenty-five years on: revisiting Bosnia and Herzegovina after implementation of a family medicine development program
}

Geoffrey Hodgetts $^{1 *}$ (D), Glenn Brown ${ }^{1}$, Olivera Batić-Mujanović ${ }^{2}$, Larisa Gavran ${ }^{3}$, Zaim Jatićc ${ }^{4}$, Maja Račić ${ }^{5}$, Gordana Tešanović ${ }^{\text {, Amra Zalihić }}{ }^{7}$, Mary Martin ${ }^{8}$ and Richard Birtwhistle ${ }^{1}$

Correction to: BMC Fam Pract (2020) 21:7

https://doi.org/10.1186/s12875-020-1079-4

Following publication of the original article [1], the authors opted to correct the name of co-author Amra Zalihić from Zahilić to Zalihić. The original article has been corrected.

\begin{abstract}
Author details
'Department of Family Medicine, Faculty of Health Sciences, Queen's University, Haynes Hall, 115 Clarence Street, Kingston, Ontario K7L 3N6, Canada. ${ }^{2}$ Department of Family Medicine, Faculty of Medicine, University of Tuzla, Tuzla, Bosnia and Herzegovina. ${ }^{3}$ Department of Family Medicine, Faculty of Medicine, University of Zenica, Zenica, Bosnia and Herzegovina. ${ }^{4}$ Department of Family Medicine, Faculty of Medicine, University of Sarajevo, Sarajevo, Bosnia and Herzegovina. ${ }^{5}$ Department of Family Medicine, Faculty of Medicine, University of East Sarajevo, Foča, Bosnia and Herzegovina. ${ }^{6}$ Department of Family Medicine, Faculty of Medicine, University of Banja Luka, Banja Luka, Bosnia and Herzegovina. ${ }^{7}$ Department of Family Medicine, Faculty of Medicine, University of Mostar, Mostar, Bosnia and Herzegovina. ${ }^{8}$ Department of Family Medicine, Center for Studies in Primary Care, Queen's University, Kingston, Canada.
\end{abstract}

Published online: 27 January 2020

\section{Reference}

1. Hodgetts G, Brown G, Batić-Mujanović O, et al. Twenty-five years on: revisiting Bosnia and Herzegovina after implementation of a family medicine development program. BMC Fam Pract. 2020;21:7. https://doi.org/ 10.1186/s12875-020-1079-4

The original article can be found online at https://doi.org/10.1186/s12875020-1079-4

* Correspondence: geoffrey.hodgetts@dfm.queensu.ca

'Department of Family Medicine, Faculty of Health Sciences, Queen's

University, Haynes Hall, 115 Clarence Street, Kingston, Ontario K7L 3N6,

Canada 